\title{
Estimating the effect of the deleterious recessive haplotypes AH1 and AH2 on reproduction performance of Ayrshire cattle
}

\author{
A. R. Guarini, ${ }^{1}$ M. Sargolzaei, ${ }^{1,2}$ L. F. Brito, ${ }^{1,3}$ V. Kroezen, ${ }^{1}$ D. A. L. Lourenco, ${ }^{4}$ C. F. Baes, ${ }^{1}$ F. Miglior, ${ }^{1,5}$ \\ J. B. Cole, ${ }^{6}$ and F. S. Schenkel ${ }^{1 *}$ \\ ${ }^{1}$ Centre for Genetic Improvement of Livestock, Department of Animal Biosciences, University of Guelph, Guelph, Ontario N1G 2W1, Canada \\ ${ }^{2}$ Select Sires Inc., Plain City, $\mathrm{OH} 43064$ \\ ${ }^{3}$ Department of Animal Sciences, Purdue University, West Lafayette, IN 47907 \\ ${ }^{4}$ Department of Animal and Dairy Science, University of Georgia, Athens 30602 \\ ${ }^{5}$ Canadian Dairy Network, Guelph, Ontario N1K 1E5, Canada \\ ${ }^{6}$ Animal Genomics and Improvement Laboratory, Agricultural Research Services, USDA, Beltsville, MD 20705
}

\section{ABSTRACT}

The effects of 2 deleterious recessive haplotypes on reproduction performance of Ayrshire cattle, Ayrshire Haplotype 1 (AH1) and Ayrshire Haplotype 2 (AH2), were investigated in Canadian Ayrshire cattle. We calculated their phenotypic effects on stillbirth (SB) rate and $56-\mathrm{d}$ nonreturn rate (NRR) by estimating the interaction of service sire carrier status with maternal grandsire carrier status using the official Canadian evaluation models for those 2 traits. The interaction term included 9 subclasses for the 3 possible statuses of each bull: haplotype carrier, noncarrier, or not genotyped. For AH1, 394 carriers and 1,433 noncarriers were available, whereas 313 carriers and 1,543 noncarriers were available for the AH2 haplotype. The number of matings considered for SB was 34,312 for heifers (first parity) and 115,935 for cows (later parities). For NRR, 49,479 matings for heifers and 160,528 for cows were used to estimate the haplotype effects. We observed a negative effect of $\mathrm{AH} 1$ on SB rates, which was $2.0 \%$ higher for matings of AH1-carrier sires to dams that had an AH1-carrier sire; this effect was found for both heifers and cows. However, AH1 had small, generally nonsignificant effects on NRR. The AH2 haplotype had a substantial negative effect on NRR, with $5.1 \%$ more heifers and $4.0 \%$ more cows returning to service, but the effects on SB rates were inconsistent and mostly small effects. Our results validate the harmful effects of $\mathrm{AH} 1$ and $\mathrm{AH} 2$ on reproduction traits in the Canadian Ayrshire population. This information will be of great interest for the dairy industry, allowing producers to

Received July 11, 2018.

Accepted February 18, 2019.

*Corresponding author: schenkel@uoguelph.ca make mating decisions that would reduce reproductive losses.

Key words: 56-day nonreturn rate, genetic evaluation, phenotypic effects, recessive disorders, stillbirth

\section{INTRODUCTION}

The rapid and advanced development of genomic technologies has revolutionized modern livestock breeding programs, especially in dairy cattle, enabling early selection of breeding animals based on genomic EBV and genomic tests, such as those for lethal haplotypes or single genes. Genomic selection has brought significant improvements in productivity and profitability in dairy cattle breeding programs due to intensive genetic selection for production and conformation traits (e.g., milk yield). However, genetic improvement of traits related to health and reproduction/fertility is limited especially due to lower heritability values, lower accuracy of measurements, and less data on phenotypes compared with production and conformation traits. Moreover, the extensive use of elite sires through AI in the dairy industry has led to increased annual inbreeding rates, which negatively effects fitness traits (Pryce et al., 2014). Most dairy cattle breeds in Canada are genetically small populations that originated from a limited number of founders. Melka et al. (2013) reported effective population sizes for 5 Canadian breeds, ranging from 40 for Canadienne to 66 for Milking Shorthorn. The authors also investigated the effective number of ancestors and found the lowest number for the Ayrshire breed, indicating intensive use of a few sires of superior genetic merit and higher selection intensity for this breed. These findings could explain observations of increased inbreeding levels and loss of genetic diversity in this breed over the past 5 decades (Sewalem et al., 2006; Melka et al., 2013). More recently, the average inbreeding levels for heifers born in 2016 were reported 
to be $7.34 \%, 6.96 \%, 6.43 \%$, and $6.36 \%$ for Holstein, Brown Swiss, Ayrshire, and Jersey breeds, respectively (Canadian Dairy Network, 2017).

A reduction in genetic variance is expected with higher levels of inbreeding, thus shrinking the potential for genetic gains (Falconer and Mackay, 1996). Furthermore, inbreeding can negatively affect fitness traits, including fertility and reproduction, by increasing the frequency of homozygous deleterious recessive alleles in the population, which can have an unfavorable effect on the profitability of the production system (Pryce et al., 2014). Previous studies have already identified genomic regions associated with female fertility in dairy cattle as a consequence of increased rates of inbreeding (e.g., VanRaden et al., 2011; Fritz et al., 2013; Pryce et al., 2014; Adams et al., 2016). A recently discovered haplotype on BTA17 in the Ayrshire breed, named Ayrshire Haplotype 1 (AH1) was found to be associated with juvenile mortality, developmental disorders, and reduced fertility (Cooper et al., 2014; Venhoranta et al., 2014). Cooper et al. (2014) identified the oldest Ayrshire ancestor carrying the AH1 haplotype, named Selwood Betty's Commander, which had the highest expected inbreeding for the Ayrshire breed according to another study (11.1\%; VanRaden and Smith, 1999). The intense use of Selwood Betty's Commander through $\mathrm{AI}$ and the popularity of his descendants might explain the high and steady frequencies for the AH1 haplotype found in the Ayrshire population (Cooper et al., 2014); the current estimate of the frequency of $\mathrm{AH} 1$ in the US Ayrshire population is 22.2\% (Null et al., 2017). A second recessive haplotype located on BTA3, known as Ayrshire Haplotype 2 (AH2), was also recently identified and a decreased sire conception rate was reported for its carriers (Null et al., 2017). Although lower sire conception rates were observed for $\mathrm{AH} 2$ carriers, the effect was not statistically significant, likely due to the small number $(\mathrm{n}=247)$ of matings of carrier sires with carrier maternal grandsires (MGS) available for the analysis (Null et al., 2017). The RNA polymerase 2 associated protein (RPAP2) gene was identified as the leading candidate gene in the haplotype and associated with embryonic development (Null et al., 2017). The carrier frequency of AH2 is of concern because it has grown from 6\% in 1990 to $21.7 \%$ in 2017 (Null et al., 2017).

Due to high carrier frequencies reported for AH1 and AH2 in the United States and the limited availability of data from previous studies, it is important to investigate and potentially validate the effects of such haplotypes on reproduction traits using a larger data set. Therefore, the present study aimed to (1) characterize the frequency of the recessive lethal haplotypes reported by Cooper et al. (2014) and Null et al. (2017) in the Ayrshire cattle breed using a larger Canadian data set, and (2) investigate their possible deleterious effects on stillbirth (SB) and 56-d nonreturn rate (NRR) in the Canadian Ayrshire population.

\section{MATERIALS AND METHODS}

\section{Data Sets}

Data on Ayrshire reproduction traits (SB and NRR) were extracted from the June 2017 genetic evaluation carried out by the Canadian Dairy Network (Guelph, Ontario, Canada; http://www.cdn.ca). The SB trait was defined as 0 if the calf was born dead or died within $48 \mathrm{~h}$ of birth and 1 if the calf lived more than $48 \mathrm{~h}$. When no subsequent insemination occurred between 15 and $56 \mathrm{~d}$ following the first service, NRR was coded as 1 ; otherwise, it was 0 . All traits recorded during or before the first calving were coded as parity 1 and considered heifer traits, and those measured after first calving (later parities) were considered as cow traits. Only records up to the sixth calving were kept in the data sets. After data filtering, a total of 150,247 and 210,008 records for SB and NRR were used for further analyses. Animals' haplotype status (carrier or noncarrier) was obtained from the Animal Genomics and Improvement Laboratory (ARS-USDA, Beltsville, MD), which used procedures as described in VanRaden et al. (2011). The status of animals with no haplotype status from Animal Genomics and Improvement Laboratory, which were Canadian animals, was defined based on their SNP genotype data, as described in the following section.

\section{Statistical Analyses}

The model used for the analyses included the same effects as in the animal model that is currently used in the national genetic evaluations performed by the Canadian Dairy Network in Canada (Jamrozik et al., 2005; Jamrozik and Kistemaker, 2016). In addition, this model was modified by including an interaction between haplotype carrier status of the sire of the embryo or newborn calf (service sire) and carrier status of the MGS (VanRaden et al., 2011). For heifers (first parity) the single-trait models were

$$
\begin{gathered}
\mathrm{NRR}=\mathrm{INT}+\mathrm{RYM}+\mathrm{HY}+\mathrm{Mf}+\mathrm{SS}+\mathrm{T} \\
+\mathrm{A}+\mathrm{E} \text {, and } \\
\mathrm{SB}=\mathrm{INT}+\mathrm{RYM}+\mathrm{HY}+\mathrm{AcMcX}+\mathrm{SC}+\mathrm{A}+\mathrm{E} .
\end{gathered}
$$


Similarly, for cows (later parities) the single-trait models were

$$
\begin{aligned}
\mathrm{NRR}=\mathrm{INT}+\mathrm{RYM}+\mathrm{HY}+\mathrm{ApMf}+\mathrm{SS}+\mathrm{T} \\
+\mathrm{A}+\mathrm{PE}+\mathrm{E}, \text { and } \\
\mathrm{SB}=\mathrm{INT}+\mathrm{RYM}+\mathrm{HY}+\mathrm{AcMcX}+\mathrm{SC} \\
+\mathrm{A}+\mathrm{PE}+\mathrm{E}
\end{aligned}
$$

where INT is the interaction effect between haplotype carrier statuses; RYM is region by year of birth by month of birth effect (12 classes); HY is herd by year of birth effect; Mf is month of first insemination effect; $\mathrm{AcMcX}$ is age at current calving by month of current calving by sex of calf by parity effect; ApMf is age at previous calving by month of first insemination by parity effect; $\mathrm{A}$ is the animal additive genetic effect; SS is the service sire by year of insemination effect; SC is sire of calf effect; $\mathrm{PE}$ is the permanent environment effect; $\mathrm{T}$ is $\mathrm{AI}$ technician effect, and $\mathrm{E}$ is the random error term. The terms INT, RYM, Mf, AcMcX, and ApMf were considered fixed effects, whereas all other effects were treated as random. The INT effect included 9 subclasses for the 3 possible statuses of each sire and maternal grandsire: carrier, noncarrier, or not genotyped. For the AH1 haplotype, 394 carriers and 1,433 noncarriers were available in the data, whereas for the AH2 haplotype, 313 carriers and 1,543 noncarriers were available.

At the time of this study, the status of the AH2 haplotypes was unknown for many genotyped Canadian Ayrshire animals because they were not part of the official US genomic evaluation. However, AH2 status was previously determined for 6,344 genotyped animals (1,306 carriers and 5,308 noncarriers) by the Animal Genomics and Improvement Laboratory, USDA (Beltsville, MD). To increase the number of Canadian bulls with known status for $\mathrm{AH} 2$ and with phenotypes for $\mathrm{SB}$ and NRR, the haplotype was located by searching the genotyped bulls' chromosomes with sliding windows of different sizes using the snp1101 software (Sargolzaei, 2014). Phased imputed 50K genotypes were used for the haplotype search. Only one haplotype was consistent with the already determined carrier/noncarrier status from Animal Genomics and Improvement Laboratory for AH2. Moreover, the identified haplotype was not present as homozygous in the Canadian animals and the animals' statuses were compatible with those from their parents. The haplotype was located between 50.8 and $52.3 \mathrm{Mb}$ of BTA3, which was slightly shorter (by $0.2 \mathrm{Mb}$ ) than that published by Null et al. (2017). Therefore, the animal's status for AH2 was defined based either on the Animal Genomics and Improvement Laboratory determination, if available, or on genotypic data, which had an accuracy of $99.3 \%$, when validated on animals with known status determined by the Animal Genomics and Improvement Laboratory.

Single-trait analyses of SB and NRR were performed using the BLUPF90 programs (Misztal et al., 2002), using pedigrees of 125,087 and 108,298 animals for NRR and SB, respectively. A modified version of the airemlf90 software (Misztal et al., 2002) was used to perform a $t$-test for specific contrasts between interactions.

\section{RESULTS AND DISCUSSION}

\section{Descriptive Statistics and Trait Trends}

Descriptive statistics for each trait are shown in Table 1. The total number of observations for SB was 34,312 for heifers, with $8.48 \% \mathrm{SB}$, and 115,935 records for cows, with $6.19 \%$ SB. For NRR, 49,479 observations were available for heifers and 160,529 for cows, with 67.23 and $56.74 \%$ nonreturns for heifers and cows, respectively (Table 1). Male calves represented 59 and $58 \%$ of SB (calves either born dead or dying within 48 $\mathrm{h}$ after birth) for heifers and cows, respectively (Table 2 ). This outcome accords with previous studies that reported male calves are more likely to be stillborn than female calves, which could be associated with calf size (Meyer et al., 2001; Bicalho et al., 2007; Cole et al., 2007; Sewalem et al., 2008). The total (males + females) proportion of SB was higher for heifers (16.9\%) than for cows $(12.4 \%)$.

Table 1. Descriptive statistics for stillbirth and 56-d nonreturn rate in Canadian Ayrshire

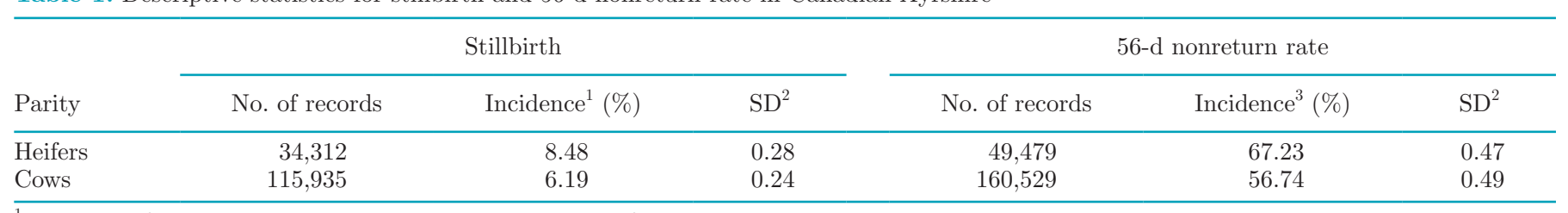

${ }^{1}$ Incidence of calves born dead or that died within $48 \mathrm{~h}$ of birth.

${ }^{2}$ Standard deviation of the phenotypic records (in the measurement scale).

${ }^{3}$ Incidence of no subsequent insemination between 15 and $56 \mathrm{~d}$ following the first service. 
Table 2. Distribution of stillbirth incidence by parity of dam and sex of calf in the analyzed data set

\begin{tabular}{|c|c|c|c|c|c|c|c|c|}
\hline \multirow[b]{3}{*}{ Score $^{1}$} & \multicolumn{4}{|c|}{ Heifers } & \multicolumn{4}{|c|}{ Cows } \\
\hline & \multicolumn{2}{|c|}{ Male } & \multicolumn{2}{|c|}{ Female } & \multicolumn{2}{|c|}{ Male } & \multicolumn{2}{|c|}{ Female } \\
\hline & $\mathrm{N}$ & $\%^{2}$ & $\mathrm{~N}$ & $\%$ & $\mathrm{~N}$ & $\%$ & $\mathrm{~N}$ & $\%$ \\
\hline $\begin{array}{l}0 \\
1 \\
\text { Total }\end{array}$ & $\begin{array}{r}1,716 \\
15,422 \\
17,138\end{array}$ & $\begin{array}{l}10.0 \\
90.0\end{array}$ & $\begin{array}{r}1,192 \\
15,982 \\
17,174\end{array}$ & $\begin{array}{r}6.9 \\
93.1\end{array}$ & $\begin{array}{r}4,191 \\
55,102 \\
59,293\end{array}$ & $\begin{array}{r}7.1 \\
92.9\end{array}$ & $\begin{array}{r}2,980 \\
53,662 \\
56,642\end{array}$ & $\begin{array}{r}5.3 \\
94.7\end{array}$ \\
\hline
\end{tabular}

${ }^{1}$ Stillbirth $=$ calves born dead or that died within $48 \mathrm{~h}$ of birth were scored as 0.

${ }^{2}$ Percentages sum to $100 \%$ within parity-sex groups.

The phenotypic trends from 1997 to 2014 for NRR and SB are shown in Figure 1. The observed NRR was higher for heifers than for cows over the entire period (average of 67.4 and $56.5 \%$, respectively), with little variation across years. The SB for heifers increased until 2009 (from 3.5 to $10.9 \%$ ), when it started to de-
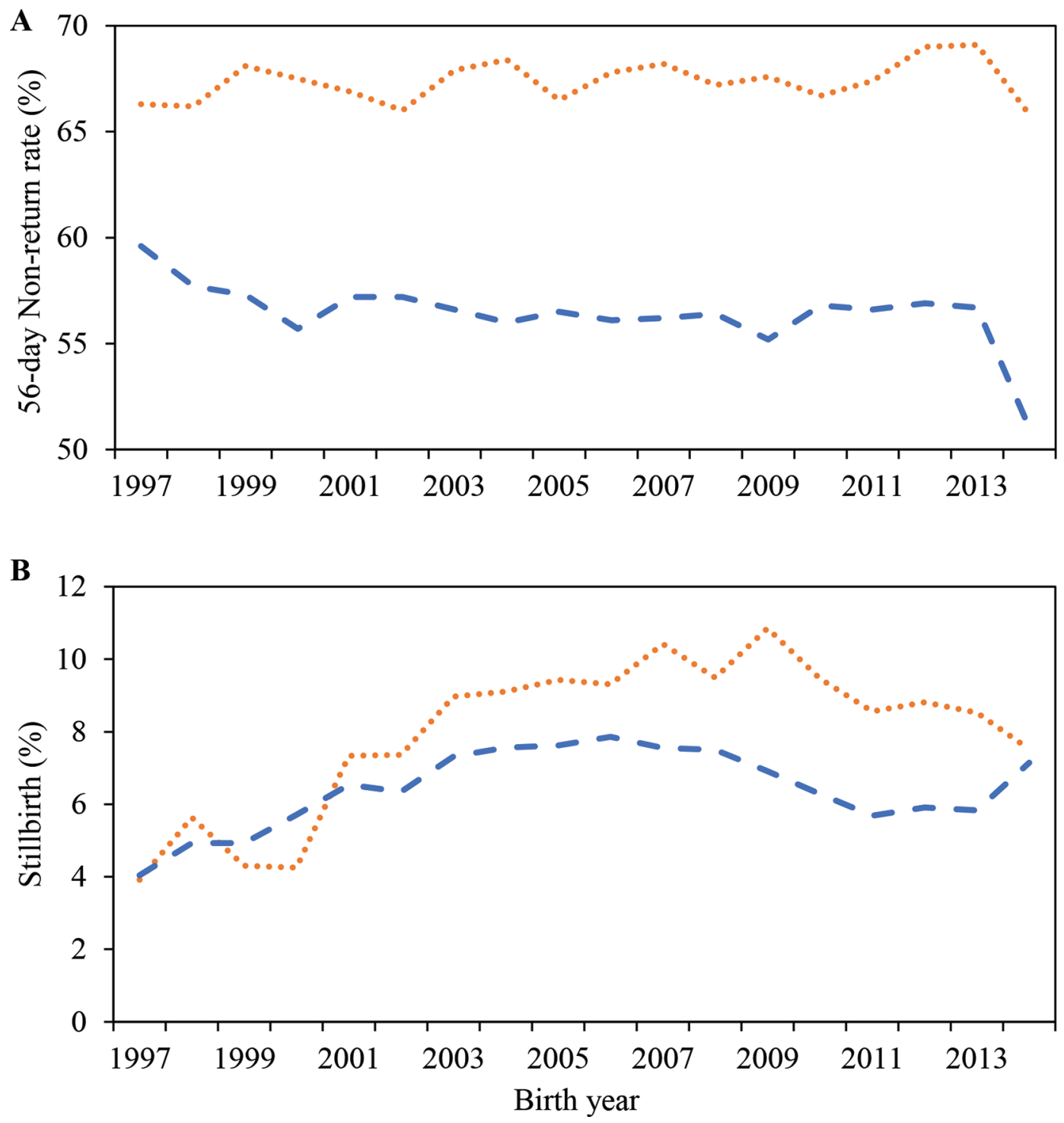

Figure 1. Phenotypic trend for 56-d nonreturn rate (A) and stillbirth (B) in heifers (dotted line) and cows (dashed line). 
crease to $7.5 \%$ in 2014. For cows, a similar trend was observed, although SB increased at a lower rate (from 3.6 to $7.1 \%$ ) until 2008 , when it started to decrease before returning to higher rates in 2011 (Figure 1).

Despite the low heritabilities estimated for SB and NRR, ranging from $1 \%$ for SB to $2 \%$ for NRR, enough additive genetic variation exists to allow effective selection for these traits (Jamrozik et al., 2005; Sewalem et al., 2010). The current Canadian Daughter Fertility index for all dairy breeds is based on age at first service (index weight $=11 \%$ ), NRR in heifers $(16 \%)$, first service to conception in heifers $(8 \%)$, calving to first service $(15 \%)$, NRR in cows (34\%), and first service to conception in cows (16\%). A higher weight is placed on NRR, which emphasizes the importance of this trait for reproductive performance in dairy cattle breeds.

\section{Haplotype AH1}

Stillbirth is an economically important trait for dairy cattle. Its occurrence is linked not only with the costs associated with the loss of a calf but also the costs associated with subsequent impaired productive and reproductive performance of cows (Mahnani et al., 2018). Thus, a better understanding of the biology underlying this trait and potentially reducing its incidence are important because it can affect the profitability of a dairy farm. Figure 2 shows the increase in the frequency of AH1 and AH2 in the Canadian Ayrshire population. Table 3 shows the observed incidence of SB and NRR by carrier status of MGS within carrier status of ser- vice sire for AH1 haplotype. Very small differences in the incidence of NRR were observed between noncarrier MGS and noncarrier service sire mating and other matings, which were mostly not significant (Table 4). Therefore, no evidence of detrimental effects of AH1 on NRR was found.

For cows, an increase of $1.4 \%$ in stillbirths was observed for carrier service sire $\times$ carrier MGS mating compared with noncarrier service sire $\times$ noncarrier MGS mating for the AH1 haplotype, whereas for heifers, a slightly higher increase $(2.1 \%)$ was observed (Table 3). These differences were highly significant $(P$ $<$ 0.001; Table 4). Other significant differences were also observed between noncarrier service sire $\times$ noncarrier MGS mating and other matings, but the magnitude of these differences in the incidence of stillbirths was much smaller (Table 4). This finding may indicate a detrimental effect on fertility, especially during mid to late gestation (VanRaden et al., 2011). Early abortion of a pregnancy, measured by return rate (and its complement NRR), would be more difficult for producers to detect, and it would also have smaller economic, welfare, and physiological effects compared with SB calves gestated for a longer period. Venhoranta et al. (2014) suggested that calves with signs of ptosis, intellectual disability, retarded growth, and mortality, which constitute an inherited disorder known as PIRM syndrome, could be associated with the AH1 haplotype. The authors identified a common region on BTA17 with extended homozygosity present in all animals with the disease, whereas no homozygosity was observed in the

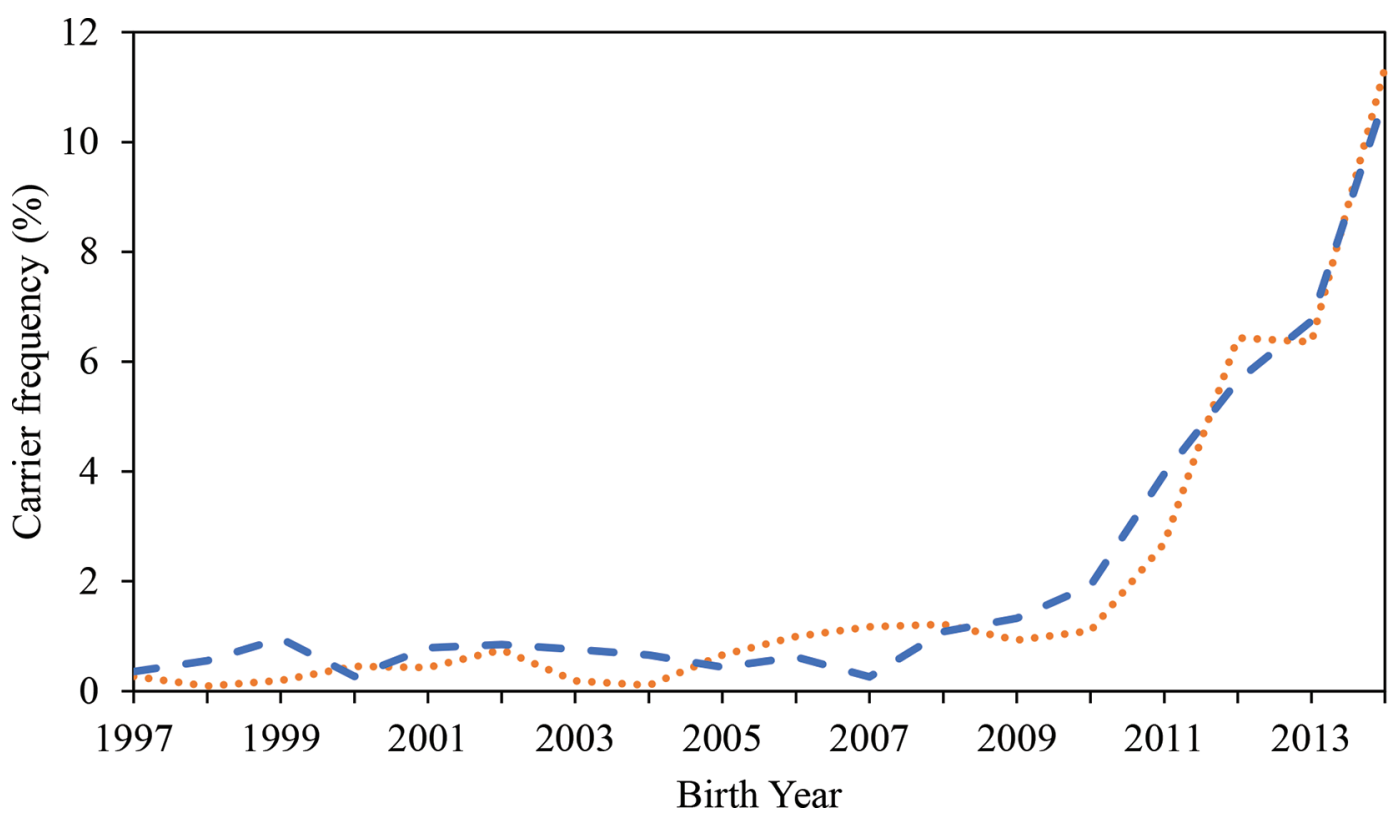

Figure 2. Frequency of recessive haplotypes AH1 (dashed line) and AH2 (dotted line) in the Canadian Ayrshire population. 
Table 3. Observed distribution of stillbirth (SB) and 56-d nonreturn rate (NRR) by carrier status of service sire within carrier status of maternal grandsire for the AH1 haplotype in Canadian Ayrshire

\begin{tabular}{|c|c|c|c|c|c|c|}
\hline Carrier status of service sire & \multicolumn{6}{|c|}{ Carrier status of maternal grandsire } \\
\hline \multicolumn{7}{|l|}{ Heifers } \\
\hline Carrier & 10.7 & 67.7 & 8.7 & 66.8 & 8.6 & 73.0 \\
\hline Noncarrier & 7.3 & 66.2 & 8.6 & 66.6 & 7.6 & 68.9 \\
\hline Carrier & 7.5 & 57.3 & 6.5 & 56.5 & 5.3 & 59.3 \\
\hline Noncarrier & 5.9 & 56.6 & 6.1 & 55.7 & 5.4 & 59.2 \\
\hline Not genotyped & 6.3 & 58.8 & 6.4 & 61.9 & 4.7 & 70.3 \\
\hline
\end{tabular}

${ }^{1}$ Calf was born dead or died within $48 \mathrm{~h}$ of birth.

${ }^{2}$ No subsequent insemination between 15 and $56 \mathrm{~d}$ following the first service.

unaffected animals, which suggests a recessive pattern of inheritance.

\section{Haplotype AH2}

As observed in Table 5 and Table 6, AH2 had a very strong and highly significant effect $(P<0.001)$ on NRR associated with carrier $\times$ carrier mating, with a decrease of more than $5 \%$ in NRR compared with noncarrier $\times$ noncarrier mating. The effect of the AH2 haplotype on SB was mostly small and inconsistent between heifers and cows, with a decrease in SB in heifers and an increase in cows (Tables 5 and 6 ). Therefore, the AH2 haplotype seems to have a much more pronounced effect on NRR than SB. Null et al. (2017) reported a

Table 4. Contrast of sire and maternal grandsire status groups against noncarrier sire and noncarrier maternal grandsire status group for the AH1 haplotype Canadian Ayrshire for heifers and cows

\begin{tabular}{llrr}
\hline Trait & Mating $^{1}$ & \multicolumn{1}{c}{$\begin{array}{c}\text { Difference } \\
( \pm \text { SE })\end{array}$} & $P$-value \\
\hline $\begin{array}{l}\text { 56-d nonreturn rate } \\
\text { Heifers }\end{array}$ & SC $\times$ MC & $0.004 \pm 0.011$ & 0.328 \\
& SNC $\times$ MC & $-0.004 \pm 0.007$ & 0.251 \\
& SC $\times$ MNC & $-0.008 \pm 0.011$ & 0.178 \\
& & & \\
Cows & SC $\times$ MC & $0.011 \pm 0.008$ & 0.073 \\
& SNC $\times$ MC & $0.011 \pm 0.005$ & 0.014 \\
SC $\times$ MNC & $0.002 \pm 0.008$ & 0.417 \\
Heillbirth & & & \\
& SC $\times$ MC & $0.023 \pm 0.008$ & 0.000 \\
& SNC $\times$ MC & $-0.008 \pm 0.005$ & 0.001 \\
SC $\times$ MNC & $0.002 \pm 0.008$ & 0.285 \\
& SC $\times$ MC & $0.020 \pm 0.003$ & 0.000 \\
& SNC $\times$ MC & $0.001 \pm 0.002$ & 0.106 \\
& SC $\times$ MNC & $0.006 \pm 0.003$ & 0.000 \\
\hline
\end{tabular}

${ }^{1} \mathrm{SC} \times \mathrm{MC}=$ carrier service sire $\times$ carrier maternal grandsire; $\mathrm{SNC} \times$ $\mathrm{MC}=$ noncarrier service sire $\times$ carrier maternal grandsire; $\mathrm{SC} \times \mathrm{MNC}$ $=$ carrier service sire $\times$ noncarrier maternal grandsire . reduction of $6.1 \%$ on sire conception rate for matings of carrier sires to cows with carrier MGS. Together, these results may indicate that $\mathrm{AH} 2$ has an early-acting effect leading to embryonic losses. Embryonic loss is of high concern, especially for high-producing cows, and it accounts for the majority of pregnancy loss events in dairy cattle (Diskin et al., 2006; Wiltbank et al., 2016). Moreover, embryonic lethality is often difficult to observe, thereby leading to increased frequencies of the haplotype in the population. Thus, the early-acting effect observed for AH2 might have played an important role in the increase of carrier frequency in the population because a carrier cow with an affected embryo can be inseminated again and carry a pregnancy with more than $50 \%$ chance of giving birth to a carrier calf.

Due to intensive selection and reduced effective population size, most dairy cattle breeds display increased inbreeding rates, and an unfavorable effect on production efficiency and fertility is expected (Wiggans et al., 2017). Moreover, higher inbreeding rates can lead to expression of recessive defects, which has become an increasingly common issue. Other recessive haplotypes have been identified in other breeds, such as BH1 and BH2 in Brown Swiss (VanRaden et al., 2011; Schwarzenbacher et al., 2016); HCD, HH1, and HHM in Holstein (Duchesne et al., 2006; Adams et al., 2012; Menzi et al., 2016); and JH1 and JH2 in Jersey (Sonstegard et al., 2013; VanRaden et al., 2014). The advent of genomic selection (and the associated genotyping), along with large phenotypic and pedigree databases, has enabled the identification and assessment of the effect of such recessive lethal haplotypes. Strategic actions should be taken to properly address the issue of increasing incidences of deleterious recessive haplotypes in the dairy populations. However, complete elimination of carriers could have a downside if not efficiently performed with a well-designed breeding plan. For instance, effective 
Table 5. Observed distribution of stillbirth (SB) and 56-d nonreturn rate (NRR) by carrier status of service sire within carrier status of maternal grandsire for the AH2 haplotype in Canadian Ayrshire

\begin{tabular}{|c|c|c|c|c|c|c|}
\hline \multirow{2}{*}{ Carrier status of service sire } & \multicolumn{6}{|c|}{ Carrier status of maternal grandsire } \\
\hline & \multicolumn{2}{|c|}{ Carrier } & \multicolumn{2}{|c|}{ Noncarrier } & \multicolumn{2}{|c|}{ Not genotyped } \\
\hline \multicolumn{7}{|l|}{ Heifers } \\
\hline Carrier & 7.4 & 61.9 & 8.7 & 66.4 & 6.6 & 71.3 \\
\hline Noncarrier & 8.9 & 67.2 & 8.5 & 67.0 & 7.9 & 70.5 \\
\hline \multicolumn{7}{|l|}{ Cows } \\
\hline Carrier & 6.7 & 51.6 & 6.7 & 56.3 & 5.6 & 59.2 \\
\hline Noncarrier & 7.1 & 55.9 & 5.9 & 56.8 & 5.4 & 59.6 \\
\hline Not genotyped & 5.9 & 62.6 & 6.2 & 61.2 & 4.5 & 70.7 \\
\hline
\end{tabular}

${ }^{1}$ Calf was born dead or died within $48 \mathrm{~h}$ of birth.

${ }^{2}$ No subsequent insemination between 15 and $56 \mathrm{~d}$ following the first service.

population size as well as the genetic variability could be substantially reduced. These outcomes could generate inbreeding depression in fitness traits and, as a result, cause a reduction of genetic gain. Implementing a mating program in which the probabilities of an animal being a carrier are taken into account to prevent carrier males from being mated to carrier females could be an efficient strategy.

To our knowledge, the literature contains no other reports on the association of haplotypes $\mathrm{AH} 1$ and $\mathrm{AH} 2$ with NRR. Thus, the results reported here contribute to further understanding the association of haplotypes $\mathrm{AH} 1$ and $\mathrm{AH} 2$ with important reproduction traits in Canadian Ayrshire population.

Table 6. Contrast of sire and maternal grandsire status groups against noncarrier sire and noncarrier maternal grandsire status group for the AH2 haplotype Canadian Ayrshire for heifers and cows

\begin{tabular}{llrr}
\hline Trait & Mating & \multicolumn{1}{c}{$\begin{array}{c}\text { Difference } \\
( \pm \mathrm{SE})\end{array}$} & $P$-value \\
\hline $\begin{array}{l}\text { 56-d nonreturn rate } \\
\text { Heifers }\end{array}$ & SC $\times \mathrm{MC}$ & $-0.051 \pm 0.013$ & 0.000 \\
& SNC $\times \mathrm{MC}$ & $0.003 \pm 0.011$ & 0.377 \\
& SC $\times$ MNC & $-0.008 \pm 0.006$ & 0.082 \\
Cows & SC $\times$ MC & $-0.040 \pm 0.008$ & 0.000 \\
& SNC $\times$ MC & $-0.002 \pm 0.006$ & 0.374 \\
Stillbirth & SC $\times$ MNC & $-0.001 \pm 0.005$ & 0.443 \\
Heifers & SC $\times$ MC & $-0.019 \pm 0.010$ & 0.000 \\
& SNC $\times$ MC & $-0.003 \pm 0.008$ & 0.231 \\
& SC $\times$ MNC & $-0.003 \pm 0.005$ & 0.097 \\
Cows & SC $\times$ MC & $0.002 \pm 0.005$ & 0.207 \\
& SNC $\times$ MC & $0.007 \pm 0.005$ & 0.000 \\
& SC $\times$ MNC & $0.004 \pm 0.003$ & 0.000 \\
\hline
\end{tabular}

${ }^{1} \mathrm{SC} \times \mathrm{MC}=$ carrier service sire $\times$ carrier maternal grandsire; $\mathrm{SNC} \times$ $\mathrm{MC}=$ noncarrier service sire $\times$ carrier maternal grandsire; $\mathrm{SC} \times \mathrm{MNC}$ $=$ carrier service sire $\times$ noncarrier maternal grandsire.

\section{CONCLUSIONS}

The effects of 2 deleterious haplotypes, AH1 and AH2, were evaluated in the Canadian Ayrshire population. For the AH1 haplotype, a substantial increase in SB rate was observed for matings of carrier service sire $\times$ carrier MGS for both heifers and cows, whereas the AH2 haplotype was associated with a substantial reduction in 56-d NRR. We speculate that AH2 causes early embryonic mortality, whereas the effect of AH1 occurs much later during pregnancy. Action should be taken to prevent an increase in the frequency of AH1 and AH2 carriers in the Ayrshire population because they have important economic and welfare implications to the industry. The effects of AH1 and AH2 haplotypes on other reproductive traits and using whole-genome sequence data will be investigated next.

\section{ACKNOWLEDGMENTS}

This research was supported in main part by Agriculture and Agri-Food Canada (Ottawa, ON, Canada) and by additional contributions from Dairy Farmers of Canada (Ottawa, ON, Canada), the Canadian Dairy Network (Guelph, ON, Canada), and the Canadian Dairy Commission (Ottawa, ON, Canada) under the Agri-Science Clusters Initiative. The first author is grateful to CAPES (Brazilian Federal Agency for Support and Evaluation of Graduate Education, Brazil) for financial support.

\section{REFERENCES}

Adams, H. A., T. Sonstegard, P. M. VanRaden, D. J. Null, C. Van Tassell, and H. Lewin. 2012. Identification of a nonsense mutation in APAF1 that is causal for a decrease in reproductive efficiency in dairy cattle. Poster P0555 in Plant and Animal Genome XX Meeting, San Diego, CA. PAG committee, San Diego, CA. https://pag .confex.com/pag/xx/webprogram/Paper3932.html. 
Adams, H. A., T. S. Sonstegard, P. M. VanRaden, D. J. Null, C. P. Van Tassell, D. M. Larkin, and H. A. Lewin. 2016. Identification of a nonsense mutation in APAF1 that is likely causal for a decrease in reproductive efficiency in Holstein dairy cattle. J. Dairy Sci. 99:6693-6701. https://doi.org/10.3168/jds.2015-10517.

Bicalho, R. C., K. N. Galvão, S. H. Cheong, R. O. Gilbert, L. D. Warnick, and C. L. Guard. 2007. Effect of stillbirths on dam survival and reproduction performance in Holstein dairy cows. J. Dairy Sci. 90:2797-2803. https://doi.org/10.3168/jds.2006-504.

Canadian Dairy Network. 2017. Inbreeding update. Accessed Sep. 11, 2017. https: / www.cdn.ca/document.php?id $=475$.

Cole, J. B., G. R. Wiggans, and P. M. Vanraden. 2007. Genetic evaluation of stillbirth in United States Holsteins using a sire-maternal grandsire threshold model. J. Dairy Sci. 90:2480-2488. https://doi .org/10.3168/jds.2006-435.

Cooper, T. A., G. R. Wiggans, D. J. Null, J. L. Hutchison, and J. B. Cole. 2014. Genomic evaluation, breed identification, and discovery of a haplotype affecting fertility for Ayrshire dairy cattle 1. J. Dairy Sci. 97:3878-3882. https://doi.org/10.3168/jds.2013-7427.

Diskin, M. G., J. J. Murphy, and J. M. Sreenan. 2006. Embryo survival in dairy cows managed under pastoral conditions. Anim. Reprod. Sci. 96:297-311. https://doi.org/10.1016/j.anireprosci.2006 .08 .008

Duchesne, A., M. Gautier, S. Chadi, C. Grohs, S. Floriot, Y. Gallard, G. Caste, A. Ducos, and A. Eggen. 2006. Identification of a doublet missense substitution in the bovine LRP4 gene as a candidate causal mutation for syndactyly in Holstein cattle. Genomics $88: 610-621$.

Falconer, D. S., and T. F. Mackay. 1996. Introduction to Quantitative Genetics. 4th ed. Pearson, Harlow, UK.

Fritz, S., A. Capitan, A. Djari, S. C. Rodriguez, A. Barbat, A. Baur, C. Grohs, B. Weiss, M. Boussaha, D. Esquerré, C. Klopp, D. Rocha, and D. Boichard. 2013. Detection of haplotypes associated with prenatal death in dairy cattle and identification of deleterious mutations in GART, SHBG and SLC37A2. PLoS One 8:e65550. https://doi.org/10.1371/journal.pone.0065550.

Jamrozik, J., J. Fatehi, G. J. Kistemaker, and L. R. Schaeffer. 2005. Estimates of genetic parameters for Canadian Holstein female reproduction traits. J. Dairy Sci. 88:2199-2208. https://doi.org/10 .3168/jds.S0022-0302(05)72895-2.

Jamrozik, J., and G. J. Kistemaker. 2016. Updated genetic parameters for Holstein reproductive traits using more recent data. Research report to the Dairy Cattle Breeding and Genetics Committee, March 15, 2016. Canadian Dairy Network, Guelph Canada. Accessed Mar. 25, 2019. https://www.cdn.ca/Articles/ GEBAPR2016/3_New\%20RP\%20Parameters\%20-\%20Janusz.pdf.

Mahnani, A., A. Sadeghi-Sefidmazgi, and H. Keshavarzi. 2018 Performance and financial consequences of stillbirth in Holstein dairy cattle. Animal 12:617-623. https://doi.org/10.1017/ S1751731117002026.

Melka, M. G., K. Stachowicz, F. Miglior, and F. S. Schenkel. 2013. Analyses of genetic diversity in five Canadian dairy breeds using pedigree data. J. Anim. Breed. Genet. 130:476-486. https://doi .org/10.1111/jbg.12050.

Menzi, F., N. Besuchet-Schmutz, M. Fragnière, S. Hofstetter, V. Jagannathan, T. Mock, A. Raemy, E. Studer, K. Mehinagic, N. Regenscheit, M. Meylan, F. Schmitz-Hsu, and C. Drögemüller. 2016. A transposable element insertion in APOB causes cholesterol deficiency in Holstein cattle. Anim. Genet. https://doi.org/10.1111/ age. 12410

Meyer, C. L., P. J. Berger, K. J. Koehler, J. R. Thompson, and C. G. Sattler. 2001. Phenotypic trends in incidence of stillbirth for Holsteins in the United States. J. Dairy Sci. 84:515-523. https:// doi.org/10.3168/jds.S0022-0302(01)74502-X.
Misztal, I., S. Tsuruta, T. Strabel, B. Auvray, T. Druet, and D. H. Lee. 2002. BLUPF90 and related programs (BGF90). Proc. 7th World Congr. Genet. Appl. Livest. Prod. 33:743-744. http://www.wcgalp .org/proceedings/2002.

Null, D. J., J. L. Hutchison, D. M. Bickhart, P. M. Van Raden, and J. B. Cole. 2017. Discovery of a haplotype affecting fertility in Ayrshire dairy cattle and identification of a putative causal variant. J. Dairy Sci. 100(Suppl. 2):199. (Abstr.)

Pryce, J. E., M. Haile-Mariam, M. E. Goddard, and B. J. Hayes. 2014. Identification of genomic regions associated with inbreeding depression in Holstein and Jersey dairy cattle. Genet. Sel. Evol 46:71. https://doi.org/10.1186/s12711-014-0071-7.

Sargolzaei, M. 2014. SNP1101 User's Guide. Version 1.0. HiggsGene Solutions Inc., Guelph, ON, Canada.

Schwarzenbacher, H., J. Burgstaller, F. R. Seefried, C. Wurmser, M. Hilbe, S. Jung, C. Fuerst, N. Dinhopl, H. Weissenböck, B. FuerstWaltl, M. Dolezal, R. Winkler, O. Grueter, U. Bleul, T. Wittek, R. Fries, and H. Pausch. 2016. A missense mutation in TUBD1 is associated with high juvenile mortality in Braunvieh and Fleckvieh cattle. BMC Genomics 17:400. https://doi.org/10.1186/s12864 $-016-2742-y$

Sewalem, A., G. J. Kistemaker, and F. Miglior. 2010. Relationship between female fertility and production traits in Canadian Holsteins. J. Dairy Sci. 93:4427-4434.

Sewalem, A., G. J. Kistemaker, F. Miglior, and B. J. Van Doormaal 2006. Analysis of inbreeding and its relationship with functional longevity in Canadian dairy cattle. J. Dairy Sci. 89:2210-2216. https://doi.org/10.3168/jds.S0022-0302(06)72291-3.

Sewalem, A., F. Miglior, G. J. Kistemaker, P. Sullivan, and B. J. Van Doormaal. 2008. Relationship between reproduction traits and functional longevity in Canadian dairy cattle. J. Dairy Sci 91:1660-1668. https://doi.org/10.3168/jds.2007-0178.

Sonstegard, T. S., J. B. Cole, P. M. VanRaden, C. P. Van Tassell, D. J. Null, S. G. Schroeder, D. Bickhart, and M. C. McClure. 2013. Identification of a nonsense mutation in CWC15 associated with decreased reproductive efficiency in Jersey cattle. PLoS One 8:e54872

VanRaden, P., D. Null, J. Hutchison, D. Bickhart, and S. Schroeder. 2014. Jersey haplotype 2 (JH2). Changes to evaluation system (August 2014). Council on Dairy Cattle Breeding (CDCB), Bowie, MD.

VanRaden, P.M., and L. A. Smith. 1999. Selection and mating considering expected inbreeding of future progeny. J. Dairy Sci. 82:27712778. https://doi.org/10.3168/jds.S0022-0302(99)75534-7.

VanRaden, P. M., K. M. Olson, D. J. Null, and J. L. Hutchison. 2011. Harmful recessive effects on fertility detected by absence of homozygous haplotypes. J. Dairy Sci. 94:6153-6161. https://doi.org/10 $.3168 /$ jds.2011-4624.

Venhoranta, H., H. Pausch, K. Flisikowski, C. Wurmser, J. Taponen, H. Rautala, A. Kind, A. Schnieke, R. Fries, H. Lohi, and M. Andersson. 2014. In frame exon skipping in UBE3B is associated with developmental disorders and increased mortality in cattle. BMC Genomics 15:890. https://doi.org/10.1186/1471-2164-15-890.

Wiggans, G. R., J. B. Cole, S. M. Hubbard, and T. S. Sonstegard 2017. Genomic selection in dairy cattle: The USDA experience. Annu. Rev. Anim. Biosci. 5:309-327. https://doi.org/10.1146/ annurev-animal-021815-111422.

Wiltbank, M. C., G. M. Baez, A. Garcia-Guerra, M. Z. Toledo, P. L. J. Monteiro, L. F. Melo, J. C. Ochoa, J. E. P. Santos, and R. Sartori. 2016. Pivotal periods for pregnancy loss during the first trimester of gestation in lactating dairy cows. Theriogenology 86:239-253. https://doi.org/10.1016/j.theriogenology.2016.04.037. 